\author{
WORK AFTER RETIREMENT: \\ WORKLIFE TRANSITIONS OF CAREER PUBLIC EMPLOYESS \\ Robert L. Clark \\ Robert G. Hammond \\ Siyan Liu \\ Working Paper 26272 \\ http://www.nber.org/papers/w26272
}

\author{
NATIONAL BUREAU OF ECONOMIC RESEARCH \\ 1050 Massachusetts Avenue \\ Cambridge, MA 02138 \\ September 2019
}

The authors gratefully acknowledge funding from the Sloan Foundation, Grant Number 2013-10-20. The research reported here is part of an on-going project that is being conducted in partnership with the North Carolina Retirement Systems Division. The opinions and conclusions expressed herein are solely those of the authors and do not represent the opinions or policy of the North Carolina Retirement System, any other institution with which the authors are affiliated, or the National Bureau of Economic Research.

NBER working papers are circulated for discussion and comment purposes. They have not been peer-reviewed or been subject to the review by the NBER Board of Directors that accompanies official NBER publications.

(C) 2019 by Robert L. Clark, Robert G. Hammond, and Siyan Liu. All rights reserved. Short sections of text, not to exceed two paragraphs, may be quoted without explicit permission provided that full credit, including $\odot$ notice, is given to the source. 
Work after Retirement: Worklife Transitions of Career Public Employess

Robert L. Clark, Robert G. Hammond, and Siyan Liu

NBER Working Paper No. 26272

September 2019

JEL No. J14,J26,J45

\begin{abstract}
Engaging in paid employment after claiming retirement benefits may be an important avenue for individuals to work longer as life expectancies rise. After separating from one's career employer, individuals may engage in paid work to stay active or to supplement their current level of retirement savings or both. Individuals who choose not to work after claiming may be expressing their preference to stay retired, perhaps because their retirement income is sufficient. However, the decision to work after claiming may be driven by the lack of retirement planning and insufficient savings, while the lack of post-claiming work may reflect the inability to find adequate employment opportunities. We use administrative records merged with panel data from several surveys of public employees in North Carolina to study the decision to engage in paid work after claiming retirement benefits. More than 60 percent of active workers plan to work after claiming benefits, while only around 42 percent of the same sample of individuals have engaged in post-claiming paid work in the first few years after leaving public sector employment. Despite this gap, stated work plans are strongly predictive of actual post-claiming work behavior
\end{abstract}

Robert L. Clark

Poole College of Management

Box 7229

North Carolina State University

Raleigh, NC 27695

and NBER

robert_clark@ncsu.edu

Robert G. Hammond

Department of Economics, Finance

and Legal Studies

University of Alabama

robert.hammond@cba.ua.edu
Siyan Liu

North Carolina State University

Raleigh, NC 27695

sliu27@ncsu.edu

A data appendix is available at http://www.nber.org/data-appendix/w26272 


\section{Work after Retirement: Worklife Transitions of Career Public Employees}

\section{Introduction}

For the past three decades, labor force participation rates among older persons have been rising. ${ }^{1}$ A longer worklife is consistent with increasing life expectancy and improving health status. However, working longer does not necessarily imply delaying retirement from career jobs. Increasingly, retirement is becoming a transitional process instead of a one-time event. Individuals leave their career jobs and move on to new employment situations before permanently leaving the labor force. ${ }^{2}$

There is long literature examining the transition from career jobs to bridge jobs to complete retirement. Most of these studies focus on all retiring workers without distinguishing between public and private sector workers. There are several reasons that one might expect public retirees to have a higher incidence of return to work after retirement compared to private sector retirees. Most importantly, public employees tend to retire at younger ages. Earlier retirement decisions are driven, in part, by coverage of more generous retirement benefits such as

\footnotetext{
${ }^{1}$ The Bureau of Labor Statistics reports that the participation rate of men aged 60-64 rose from 54.3 percent in 1996 to 62.0 percent in 2016. Over the same period, the rate for men 65 and older increased from 16.9 percent to 24.0 percent. Similarly, the participation rate of women aged 60-64 increased from 38.2 percent to 50.1 percent while the rate for those aged 65 and older rose from 8.6 percent to 15.5 percent. See https://www.bls.gov/emp/tables/civilian-labor-force-participation-rate.htm.

${ }^{2}$ Cahill, Giandrea, and Quinn (2018) provide a comprehensive review of the bridge job literature. They conclude that "One well-documented finding from the retirement literature is that between one half and two thirds of older Americans with career jobs transition to a new job (a "bridge" job) before exiting the labor force” (page 346).
} 
defined benefit plans and retiree health insurance. ${ }^{3}$ The economic incentives imbedded in defined benefit pension encourage public sector employees to leave their state or local government jobs as soon as they qualify for retirement benefits. Rules regarding public sector defined benefit pension plans may limit immediate return to paid employment in public agencies in the same state or local government following retirement from a public sector job, but these regulations do not prohibit employment by private firms. ${ }^{4}$

Understanding what retirement paths individuals follow and why can help inform government and employer policies regarding benefit design and return to work provisions. We use a novel dataset comprised of three surveys merged with administrative records to examine the retirement transitions of public sector workers in North Carolina. First, we study postretirement work plans as employees approach and enter retirement from their government job. We find that more than 70 percent of workers over the age of 50 plan to engage in paid work after claiming retirement benefits. Planning for post-claiming work is associated with those who are younger, more highly educated, and have children. Among married individuals, having a currently employed spouse is positively associated with own post-claiming work plans.

\footnotetext{
${ }^{3}$ Clark, Craig, and Sabelhaus (2011) provide a discussion of the generosity of state and local retirement plans and how they vary by whether workers are also covered by Social Security. Clark and Morrill (2010) examine the retiree health plans of states and describe their generosity and funding status. ${ }^{4}$ Franzel, Young, and Liss-Levinson (2018) provide a detailed overview of return to work policies of 83 of the largest state pension plans. They find substantial differences across public plans with 40 of these plans making significant modifications to their policies since 2009. Fitzpatrick (2019) examines the impact of hours restrictions on post-retirement work by public employees and finds that raising the number of hours that retirees can work leads to increased benefit claiming and greater hours of work by retirees.
} 
Then, we study survey responses to examine the labor market participation of these individuals shortly after claiming retirement benefits. Around 42 percent of retirees have worked since claiming, which is a period of around 18 months on average. More than 40 percent of these individuals started working within 3 months of benefit claiming. We find plans to work after leaving the career job and claiming pension benefits to be positively associated with work after retirement, as are younger age and better health. As with plans, among those who are married, having a working spouse is positively associated with own work. Further, we consider separately whether individuals are working post-retirement due to insufficient retirement income and savings, or whether individuals exhibit preferences for engaging in post-retirement productive activities.

Our final analysis uses self-reported measures to gauge the financial well-being of our sample in the early years after leaving career employment. We conclude that stated retirement well-being is lower for individuals who, late in their career, reported that they planned to engage in post-claiming work, relative to those who did not plan to work. It appears that, on average, late career plans to work after claiming retirement benefits may be correlated with low selfperceived retirement preparedness.

Our findings suggest that many public workers make plans about work after retirement. Some readily realize these plans soon after benefit claiming, which may improve their retirement income security. The key policy question is whether modifications to retirement rules would increase welfare by allowing post-claiming paid work when an individual wants to work but is constrained by income or hours restrictions. Retirement plan characteristics may influence the work after retirement choices both through relatively young ages for full eligibility for benefits and through limiting options for return to work. 


\section{Background}

\section{Work after Retirement Incentives for Public Workers}

Most economic studies of the final worklife transition examine data from either the Retirement History Study (RHS) conducted between 1969 and 1979 and the more recent Health and Retirement Survey (HRS), which began in 1992 and is still ongoing. In general, studies based on these surveys do not consider differences between public and private sector workers in their transition from career jobs to complete retirement from the labor force. ${ }^{5}$

It is important to distinguish between public and private sector workers when examining their decisions to work after retirement. To begin with, work after retirement behavior may differ for those covered by a defined benefit pension (DB) plan compared to workers covered by defined contribution plans (DC) and those without any retirement benefits. The most important difference is that DB participants eligible for unreduced retirement benefits experience large opportunity costs of continued working on their career job. Thus, an individual that would prefer to continue in her job, all else equal, faces a strong incentive to terminate employment and claim retirement benefits.

The pension effect is one of the primary reasons we anticipate that public employees leave their career jobs at relative young ages. In comparison, DC participants continue to build retirement income through delayed retirement. Second, most defined benefit pension plans include a final average salary calculation based on actual earning during those years. This will incentivize individuals to work more hours per year towards the end of a career. Thus, an individual that might otherwise reduce hours on career jobs at older ages will instead face an

\footnotetext{
${ }^{5}$ An exception to this gap in the literature is the recent study by Quinn, Cahill, and Gianrea (2019 forthcoming).
} 
incentive to claim retirement benefits and shift to new jobs that have greater flexibility in hours after retirement. Since public employees are much more likely to be covered by DB plans, these retirement incentives may lead to higher proportions of early retirement and work after retirement among public workers.

Details of DB plans also vary between the public sector and the private sector. Public pension plans typically allow employees to reach the normal retirement age at relatively young ages and almost all have early retirement options that allow workers reaching age 50 with 20 or more years of service to retire at a reduced benefit. A worker covered by a defined benefit pension without a minimum age requirement could potentially retire in their 50s with unreduced benefits after some minimum years of service (e.g., 30 years of service). ${ }^{6}$ In addition, many of these relatively young retirees are eligible to remain in their employer's health plan, which is a valuable benefit for those not yet eligible for Medicare.

Another potentially important distinction between public and private sector defined benefit pension is the default to an annuity type distribution. In the private sector, ERISA rules mandate that all DB plan participants default into a Joint and Survivor benefit and require a beneficiary's signature before electing for a single life annuity. In the public sector, there is no default option and the rate of retirees selecting single-life annuities is considerably higher. ${ }^{7}$ Thus, conditional on earnings and the benefit formula, a public sector worker will, on average,

\footnotetext{
${ }^{6}$ Many public plans allow workers to qualify for unreduced pension benefits after achieving 30 years of service while others have provisions such as the rule of 85 for normal retirement (age plus years of service). Thus, many workers qualify for full retirement benefits in their 50s.

${ }^{7}$ Clark, Hammond, and Vanderweide (2019 forthcoming) describe the differences in annuities in public and private pension plans and how defaults influence the probability of selecting a joint and survivor benefit.
} 
be receiving a higher monthly benefit. Further, many public plans offer a Social Security leveling option whereby the individual receives a higher benefit up until age 62 (see Clark, et al, 2018). At that point, the benefit is reduced such that the sum of the pension and expected Social Security benefit is equal to the prior benefit amount. This will again provide more wealth at earlier ages, at the expense of higher benefits over the longer term. This higher wealth may disincentivize working after retirement through an "income effect.” Thus, differences in pension benefits and retiree health insurance coverage may push relatively young workers out of career jobs. We do not have a priori prediction on their tendency to work after claiming benefits. Being young and in good health, these individuals may be more likely to seek bridge jobs. However, given their lifetime benefits, they will have a lower economic need to work after retirement.

While all of these frictions are present in any defined benefit pension plan, these may be even more problematic in the public sector in terms of continued employment. First, while in the private sector there may be other firms that an individual can work at and not be subject to a pension plan-related earnings test, finding appropriate work that is not covered by the same retirement system may be challenging for public workers. Furthermore, public sector workers are often covered by strict wage schedules whereby the most experienced are paid the most. This will inhibit public employers from making accommodations for their oldest, and hence highest paid, employees.

The choice of post-career employment with the same public employer is subject to state and federal laws. Changes in federal legislation to allow in-service distributions of pension benefits after employees have attained the normal retirement age has moderated a significant 
impediment to phased retirement (Hill, 2010). ${ }^{8}$ In the public sector, the length of time between retirement and re-employment is clearly stated along with how returning to work impacts the annual pension amount. ${ }^{9}$

Public sector workers may have different preferences than private sector counterparts. There is some evidence indicating that public sector workers are more risk averse than comparable individuals who choose to work in the private sector (Bellante and Link, 1981). This greater risk aversion influences individuals to migrate toward jobs with lower turnover probabilities, DB pension plans, retiree health insurance, along with other benefits at the expense of lower lifetime earnings. Clark, Hammond, and Khalaf (2019) provide a discussion of risk and time preferences and their importance in retirement planning for public employees. Having worked for a full career with the belief of a large retirement benefit, public sector workers may be less inclined to seek employment after claiming retirement benefits.

\section{Bridge Jobs and Work after Retirement}

Over the past three decades, economists have been documenting the change in the worklife transition and the importance of individuals moving to bridge jobs (e.g., Quinn 1980, 1999, Ruhm 1990). Bridge jobs are typically defined as a job not with one’s former employer

\footnotetext{
${ }^{8}$ Allen, Clark, and Ghent (2004) and Johnson (2011) also discuss the incidence of phased retirement and why many employers are reluctant to adopt formal phased retirement programs.

${ }^{9}$ In North Carolina, there is a six-month mandatory work break for teachers and state employees and a one-month mandatory work break for local government employees after claiming pension benefits. Workers who return to work for a public employer in the same benefit system also face restraints in the number of hours worked and earnings in order to continue receiving benefits. The rules governing return to work for state retirees in North Carolina are defined in https://www.nctreasurer.com/ret/Return\%20to\%20Work/RTWGuidanceTSERS.pdf, while the regulations for employees of local governments are described at https://www.nctreasurer.com/ret/Return\%20to\%20Work/RTWGuidanceLGERS.pdf.
} 
that has fewer hours and less responsibility, acting as a bridge from full time work to complete retirement. Clark and Morrill (2017) find that the first transition of 20 percent of career employees in the 1992 HRS cohort was to a bridge job with an additional 5 percent moving into self-employment. ${ }^{10}$ Individuals who leave career employers but choose not to move directly into complete retirement may be seeking new challenges in different types of jobs or they may be looking for jobs with less physical or mental stress.

A series of studies indicate that the new norm of retirement is to gradually transition from full-time work with a career employer to an additional period of employment prior to leaving the labor force permanently. ${ }^{11}$ Giandrea, Cahill, and Quinn (2009) find that 60 percent of individuals leaving full-time career jobs ultimately moved to bridge jobs instead of permanently retiring. The transition often includes changes in occupations, industries, and hours of work. For example, Giandrea, Cahill, and Quinn (2009) show that 46 percent of men and 54 percent of women transiting to bridge jobs were working part-time for the cohort aged between 59 and 64 in 2006. Johnson, Kawachi, and Lewis (2009) find that two thirds of older job changers switched occupations and that hourly wages were substantially lower in their bridge jobs. They note that bridge jobs tend to be less stressful, have more flexible work schedules, and are less likely to have health insurance.

The probability of a gradual transition into retirement is found to be affected by the age of termination of career job, health status at retirement, and type of pension in which the

\footnotetext{
${ }^{10}$ This analysis of transitions is based on comparing the employment status in one wave of the HRS to the next wave, which is two years later. Thus, what is reported as a change in status for a career job to a bridge job could have involved some period of time out of the labor force.

${ }^{11}$ For some individuals, the retirement transition includes a movement into self-employment where hours and work assignments can be more flexible (Giandrea, Cahill, and Quinn, 2008).
} 
individual was enrolled. Cahill, Giandrea, and Quinn (2006) examine ten years of data from the HRS and find that the tendency to move to a post-career bridge job is positively correlated with young age, good health, number of dependent children, and the lack of health insurance coverage on full-time career jobs. They also find that those with both defined benefit and defined contribution pension plans likely to hold a bridge job. Quinn, Cahill, and Giandrea (2019) is one of the few studies to directly compare the retirement transition in public sector to that of private sector workers. They find that gradual retirements of public sector career workers are very similar to those in the private sector. They conclude that public-sector workers are not more likely than private-sector workers to choose one-time, permanent exits from the labor force. The present study builds on this analysis but focuses solely on public retirees and their tendency to work after retirement from full-time career jobs using surveys that were developed specifically to examine the retirement transition.

\section{Unretirements and Labor Force Reentry}

Subsequent to retirement from full-time career jobs or bridge jobs, the worklife transition may include a period of non-employment followed by the return to the labor force. The decision to re-enter the labor force after a period of nonparticipation may be part of an ex ante retirement plan. Alternatively, re-entry may not be planned at the time of retirement. Instead, unexpected economic events, such as a shock to retirement wealth due to market fluctuations or changes in family circumstances, can create a renewed need for income. Thus, return to work or the movement to bridge jobs may be due to bad planning or unanticipated events may have resulted in a change in the optimal work plans in retirement. We are unable to test the magnitude of these two hypotheses on the reasons for work after retirement. 
Maestas (2010) uses the HRS to examine the tendency of individuals to return to work after retiring and completely leaving the labor force. She finds that between 27 and 37 percent of individuals who moved from work to full retirement reversed their retirement decisions and reentered the labor market. Some of these re-entries were planned while individuals were still on their career jobs and some were the result of unanticipated events in the post-retirement period. She finds that the jobs obtained by these individuals are similar to the bridge jobs of those that move from career jobs to new employment.

Zissimopoulos and Karoly (2009) examine data from the HRS from 1992 to 2002 and find that 5 percent of retirees found new employers between waves of the survey and that about one third of those who had left the labor force moved into self-employment. Cahill, Giandrea, and Quinn (2011) estimate that about 15 percent of career employees who exited the labor force returned to work. As might be expected, younger and healthier individuals are more likely to return to the labor force. Taken together, the limited research on labor force re-entry by retirees indicates that complete withdrawal from the labor force is not a permanent state for many individuals and that re-entering the labor force after a period of zero hours of work can be part of a lifetime plan or driven by unexpected events that occur after retirement.

\section{Evidence on Public Employees in North Carolina}

This study provides a detailed assessment of retirement and work after retirement plans of older public employees in North Carolina along with the post-claiming of pension benefits work behavior of recent retirees. The analysis is based on three surveys of employees aged 50 to 69 who were working full-time in $2014 .{ }^{12}$ The analysis began when we were provided the

\footnotetext{
${ }^{12}$ The Data Appendix provides a discussion of these surveys and the sample construction.
} 
administrative records of all full-time state and local employees employed as of March 2014. From these data as well as a second release of administrative records as of April 2016, we drew random stratified samples of these older workers and sent detailed questionnaires asking about their future work and retirement plans. As part of a larger research project on the transition of from career jobs to retirement by public employees, we conducted several surveys, including surveys of active workers and surveys of benefit claimants. ${ }^{13}$ Surveys were fielded in spring 2014, 2016, and 2018 with individuals being linked across the surveys.

We focus on individuals for whom we have two sets of survey responses: pre-claiming (i.e., individuals employed full-time by their public sector employer) and after claiming retirement benefits. Our restriction to respondents who retired between surveys generates a sample of 590 individuals. 261 (44.2 percent of the full sample) of these individuals claimed benefits between 2014 and 2016. We refer to this sample as "Sample 1." 329 (55.8 of the full sample) claimed between 2016 and 2018, who are referred to as "Sample 2.” Table 1 presents the means of economic and demographic characteristics of all of these individuals and then separately by whether retirement occurred in the first or second time period described above. The mean age is 60.7 years as of 2016 . About 70 percent of the sample is female, and about 30 percent are teachers. ${ }^{14}$ The respondents are mostly white with relatively high levels of education. ${ }^{15}$

\footnotetext{
${ }^{13}$ For more detail on the larger project, please see: https://sites.google.com/site/publicsectorretirement/.

${ }^{14}$ We define teachers as those who have the job classification "Education professionals" in our administrative records.

${ }^{15}$ The data are from two samples, and the sample construction is described in more detail in the Data Appendix. For the second sample, the administrative records do not include information on years of service. The other variables are observed consistently across the two samples.
} 
[Table 1]

All full-time employees working for a state agency in North Carolina, as well as teachers employed by local public school systems, are required to enroll in the Teachers and State Employees Retirement System (TSERS). Most municipal, county, and other local governmental employers participate in Local Government Employees Retirement System (LGERS). Both plans are defined benefit pension plans and are managed through the office of the State Treasurer. The benefit formula for TSERS is 1.82 percent of the employees' final average salary per year of creditable service while the LGERS benefit is based on 1.85 percent per year of service. Both plans provide an unreduced benefit for individuals at any age with 30 years of service, at age 62 with 20 years of service, or at age 65 with 5 years of service. Thus, individuals who entered public employment in NC immediately after completing high school or college could be eligible for an unreduced benefit beginning around age 50. Early retirement benefits are available to individuals who attain age 50 with 20 years of service. ${ }^{16}$

Both state and local employees along with teachers are also covered by Social Security. Most of those who are covered by TSERS are also eligible to remain in the state health plan after retirement. Some local governments also cover employees and retirees in the state health plan, while others provide their own health insurance plan. Most state and many local employees are also eligible to participate in the two state-managed voluntary supplemental retirement saving plans, the NC 401(k) Plan and the NC 457 Plan, in addition to other voluntary supplemental

\footnotetext{
${ }^{16}$ Details of the benefit formulas and eligibility conditions for retirement benefits are described in the employee handbooks for both systems which can be found at https://www.nctreasurer.com/ret/Benefits\%20Handbooks/TSERShandbook.pdf https://www.nctreasurer.com/ret/Benefits\%20Handbooks/LGERShandbook.pdf.
} 
retirement saving plans administered by North Carolina public employers (i.e., local 457 plans or 403b plans for school district employees).

A key objective of this study is to examine older workers’ plans for their upcoming retirement transitions. While still employed, respondents were asked their expected retirement age, whether they plan to work after claiming retirement benefits, and why they either are or are not planning to work after claiming. Given young retirement ages of public sector employees, we might expect that many of these individuals would plan to stay engaged in the labor force after leaving public employment. Evidence on this and related points are shown in the leftmost columns of Table 2 .

[Table 2]

Among these older workers, around 69 percent indicated that they had developed a retirement plan. In terms of subjective expectations with respect to retirement standard of living, our survey questions elicited wide variability in satisfaction with retirement preparedness: 63 percent of respondents expect to have enough money to live comfortably, yet only 43 percent indicating that they are saving the right amount for retirement.

Around 80 percent of our sample responded with their post-claiming work plans. Among these 471 respondents, 357 individuals (or 76 percent) reported that they planned to work after leaving public sector employment, with the majority planning for part-time work. Thus, there is a desire among a relatively large proportion of older public sector workers to remain engaged in paid work after claiming. ${ }^{17}$ There is also evidence of a lot of uncertainty, as seen by the high

\footnotetext{
${ }^{17}$ Between 30 and 50 percent of individuals plan to work in retirement according to the HRS in studies using pooled samples of public and private sector workers (Maestas, 2010; Pienta and Hayward, 2002).
} 
proportion of individuals who responded that they did not know their plans (around 20 percent) or did not answer the question (less than 1 percent). ${ }^{18}$ Finally, we have an informative set of responses on rationales for plans to or not to work (e.g., staying active is more commonly listed than income needs as a reason for post-claiming work).

Table 3 presents descriptive statistics of these same individuals as measured after benefit claiming. These responses provide insights into the early years of retirement for these public sector workers. Our survey data give us a panel of work history since claiming, and the main measure is an indicator of whether they engaged in any post-claiming work. 247 individuals have worked for pay since benefit claiming, which is 43 percent of the 574 individuals who responded with their post-claiming work behavior. The majority of those who worked after claiming engaged in part-time work in their first job after retirement. The rightmost columns of Table 2 align the post-claiming measures with the pre-claiming measures to analyze the realization of work plans. Work plans are predictive of actual post-claiming work: 55 percent of those who planned to work have engaged in post-claiming work, which is much higher than the approximately 21 percent rate of work for those who did not plan to work or who did not know their post-claiming work plans. It is important to recognize that the time between claiming and our survey is relatively short. Thus, some of the retirees who have not yet returned to work may do so in the future so the percent of claimants who report having worked since benefit claiming should be considered an underestimate of the proportion that will ever return to paid employment.

\footnotetext{
${ }^{18}$ The “Don't know” option was not provided in the pre-retirement survey for Sample 1. The proportion of those uncertain of work plans reported in Table 2 may be underestimated.
} 
[Table 3]

Figure 1 shows the distribution of the break in months between career employment and post-claiming work, for those in our sample who engaged in post-claiming work. Around 11 percent of survey respondents report that they began work before claiming benefits. We do not know separation dates from their career employers, and presumably the majority of these individuals started at their new job very soon after leaving their career job but before claiming. Around 34 percent of this sample who worked did so within three months of claiming. This analysis focuses on the immediate post-claiming work behavior of public retirees, so we cannot address the realization of post-claiming work plans of individuals who planned a break before reentering the labor force, if this break was longer than two years.

[Figure 1]

Table 4 presents a regression analysis of plans to work after leaving public employment and claiming retirement benefits. In all regression specifications, gender and marital status are interacted. Relative to the omitted category of single females, single males are more likely to plan to work, married females are less likely, and married males are much less likely.

Respondents who are older are less likely to plan to work. African Americans are similar to whites in their plans, while individuals of other races have a large positive effect that is statistically insignificant (possibly because of our small sample of individuals other than African American or white). Those with high levels of education are much more likely to plan to engage in post-claiming work. Having children also strongly predicts a higher propensity to plan to work, with the main effect appearing to come from having children versus not, rather than an additional effect associated with more children. High financial knowledge is positively 
associated with not planning to work (around 9 percentage points). ${ }^{19}$ Finally, time-impatient or risk-averse workers are less likely to plan to work, but the coefficients are statistically insignificant. ${ }^{20}$ In a separate analysis of married retirees shown in Appendix Table B5, workers whose spouse is employed are 9 percentage points more likely to plan for work.

[Table 4]

Turning to post-claiming work behavior, Table 5 presents regression analysis of the decision to work after claiming benefits. Stated plans are predictive of actual behavior: those who planned to work are 30.1 percentage points more likely to work after claiming in Column 1. The strong effect of plans on behavior continues to hold when the model adds additional covariates. Relative to the baseline rate of post-claiming work among those not planning to work of 21.1 percent (as shown in Table 2), the increase of 30.1 percentage points more than doubles the rate of post-claiming work. We separately control for individuals who responded that they did not know their post-claiming work plans. These uncertain responses map into post-claiming work rates that are statistically indistinguishable from those who responded that they did not plan to work. This is consistent with the summary statistics in Table 2, where both set of results suggest that those answering that they do not know their plans behave like those who say they do not plan to work. Both groups work at rates around 21 percent.

\section{[Table 5]}

\footnotetext{
${ }^{19}$ Financial knowledge is objectively measured as correctly answering financial literacy survey questions. See the appendix for more details on the measurement of this and other variables.

${ }^{20}$ Time and risk preference are measured by binary indicators. See the appendix for details on these two indicators.
} 
Single males work after claiming at rates that are slightly higher than single females, but the effect is statistically insignificant; married individuals do not work a different rate than those who are not married. The effects of gender and marital status were larger and more precisely estimated for plans relative to work after claiming. One interpretation is that the effect of gender and marital status operate through plans and, conditional on plans, they do not largely affect post-claiming work. In a separate analysis of married retirees (Appendix Table B6), claimants who report that their spouse is working are 20 percentage points more likely to be working. Those who were older in their late career are less likely to work. African Americans work at much lower rates, while there is no statistically significant difference for those of other races. Individuals who report being in very good or excellent health work at meaningfully higher rates than those who reported worse health status. While having children was strongly positively predictive of planned work, having children is not associated with differential work behavior in Column 1 of Table 5.

Since most teachers are not employed for several months in the summer during their career, many have the opportunity to form work relationships that might extend after retiring from their career teaching job. These labor market contacts should make it easier to shift to a bridge job. In addition, there may be job opportunities in private schools that require identical skills to those utilized on their career job. To test the hypothesis that teachers may be more likely to work after retirement, we include an indicator variable for being an educational professional in our specification. The result shown in Table 5 indicates that, conditional on plans to work, teachers are 17-19 percent more likely to work after retirement compared to other public retirees. 
As the model is expanded to include additional covariates, parents continue to work at similar rates as non-parents, conditional on plans. However, Column 4 adds stated caregiving activities, where survey respondents were asked whether they spent time caring for certain individuals in a typical week. We categorize caregiving activities into care for own children, grandchildren, and others, where individuals can provide care for multiple individuals at the same time. ${ }^{21}$ In Column 4, individuals who are caring for children are more likely to engage in post-claiming work, with an effect size of 20.5 percentage points. The coefficients for the other two groups of care activities are not statistically significant. Conditional on plans, parents who are still caring for their children are working at much higher rates than parents who are no longer caring for their children; the latter group is working at rates that are similar to non-parents.

Post-claiming work of parents is strongly associated with the extent of care currently given to their children. We interpret stated caregiving for children as a measure of those individuals who have financially dependent children relative to financially independent children. Under this interpretation, we conjecture that parents who expect their children to remain financially dependent plan to work after claiming and frequently do so, while parents whose children are unexpectedly financially dependent might work despite having not planned to do so. The survey of active workers did not ask question about the expected future financial dependence of respondents' children, so we are not able to test this conjecture beyond pointing out that it is one interpretation of the results in Table 5.

\footnotetext{
${ }^{21}$ We do not add caregiving indicators to the model on plan to work, as information on planned caregiving in retirement is not available in the pre-claiming surveys.
} 


\section{Well-being in Retirement}

Table 6 analyzes stated well-being in the early years of retirement. The interaction of work plans and realized post-claiming work provides four groups of interest: those who neither planned to work nor worked (the reference group), those who planned to work but did not work, those who worked but did not plan to work, and those who both planned to work and worked. Separately, we include an indicator for individuals who reported that they did not know their work plans. Those with uncertain work plans are sometimes statistically distinguishable from those who did not plan to work, but the rationale for including this indicator is to control for differences among those with uncertain plans to make a clean comparison of those individuals who did and did not plan to work after claiming.

[Table 6]

In the following analysis, we examine how planning to work after retirement while working and actually working after retirement influence six different measures or indicators of satisfaction in retirement. The dependent variables in the well-being regressions are self-reported agreement with the following statements: (1) made the best decisions concerning retirement timing, (2) made the best decisions concerning annuity choice, (3) had enough information to make informed retirement decisions, (4) saved enough for retirement while working, (5) confident of not outliving savings, and (6) satisfied with standard of living in retirement. These subjective well-being measures provide insight into the outcomes early in retirement years.

The coefficient on plan to work represents the comparison of those who planned to work but did not work, relative to those who neither planned to work nor worked. Having a plan to work not realized could suggest a positive retirement well-being shock or an inability to find 
adequate work. We find that those whose plan to work was not realized are doing worse than those with a realized plan to not work. Individuals whose plan to work were not realized are statistically significantly less likely to say they saved enough (Column 4), less confident in their retirement savings (Column 5), and less satisfied with their post-claiming standard of living (Column 6). These individuals appear to have low well-being in retirement, which is inconsistent with not working because of a positive shock in retirement income or another type of positive shock.

The coefficient on having worked for pay in retirement represents the comparison of those who worked but did not plan to work, relative to those who neither planned to work nor worked. Not realizing a plan not to work could suggest a positive shock to one's work prospects/capacity or a dissatisfaction with retirement savings that necessitates unplanned work. The results on having worked after claiming do not provide a clear picture: while some effects are meaningfully large, they are not statistically significant. Further, an individual might unexpectedly work because her savings are inadequate, but before responding to the survey, she may bolster her savings to a sufficient degree. It is perhaps because of this ambiguity that we cannot precisely detect the average effect of unexpected work.

The final group of individuals who planned to work and worked are represented by the sum of the coefficients for planned to work, worked, and their interaction. While Table 6 presents the three coefficients separately, we test their joint significance to detect meaningful effects for the realized plan to work group, relative to the realized not plan to work group. For those with a realized plan to work, there is evidence of lower retirement well-being: the effects are statistically significantly negative in terms of best timing (15.0 percentage points lower, pvalue $=0.01)$, saved enough $(15.8$ percentage points lower, $\mathrm{p}$-value $=0.01)$, and confident $(20.2$ 
percentage points lower, $\mathrm{p}$-value $=0.00$ ), and marginally statistically significantly negative in terms of satisfied $(10.5$ percentage points lower, $\mathrm{p}$-value $=0.10)$. In total, the early-retirement outcomes among individuals in this sample are associated with the lowest levels of stated wellbeing for individuals who planned to work and in fact worked. One interpretation is that these individuals were aware of their low levels of retirement preparedness when reporting their plan to engage in post-claiming work, which continued as they worked after claiming. ${ }^{22}$

\section{Conclusions}

A public employee who becomes eligible for retirement benefits faces a choice to delay retirement and continue working or to separate from public employment and claim retirement benefits. The latter decision is often called "retirement" even though the individual may continue engaging in paid employment for several more years. After claiming a retirement benefit, the individual might return to her previous employer in the same role or in a role with a reduced time commitment (and, potentially, compensation level). The individual may seek a bridge job at another employer or spend time not working and then re-enter the labor force. It is difficult to capture the full range of possible patterns for one's worklife transition.

This study examines the worklife transitions of career public sector employees in North Carolina. First, we assess expectations for retirement and plans for working after retirement for workers aged 50 to 69 . Career public employees plan to retire at relatively young ages, and around 60 percent older workers indicate that they plan to work after retirement. The labor market activities of these individuals are consistent with their plans in the sense that plans are

\footnotetext{
${ }^{22}$ The interpretation is supported by an alternative model specification shown in Appendix Table B7. When defining plans to work as plans to work because of insufficient income, plans to work and realizing plans to work have stronger negative associations with the rightmost three subjective wellbeing measures.
} 
strongly predictive of behavior. Around 42 percent of individuals have worked since claiming, within a period of around two years on average. Among those who planned to work, around 55 percent worked, which is much higher than the rate of around 21 percent for those who did not plan to work or reported that they did not know their plans to work. Finally, our data contain self-reported measures of the financial well-being of these individuals in the early years after claiming benefits. Stated retirement well-being is lower for individuals who, late in their career, reported that they planned to engage in post-claiming work, relative to those who did not plan to work. Our results indicate that public workers in our sample who make and realize plans to work after retirement feel less secure about their retirement income and savings. These workers may benefit from policies that better allow them to work while claiming benefits in order to increase income in retirement. 


\section{REFERENCES}

Allen, Steven, Robert Clark, and Linda Ghent. 2004. "Phasing into Retirement.” Industrial and Labor Relations Review, 58(1): 112-127.

Bellante, D. O. N., \& Link, A. N. 1981. Are Public Sector Workers More Risk Averse Than Private Sector Workers ? Industrial and Labor Relations Review, 34(3), 408-412.

Cahill, Kevin, Michael Giandrea, and Joseph Quinn. 2006. "Retirement Patterns from Career Employment.” The Gerontologist 46 (4): 514-523.

Cahill, Kevin, Michael Giandrea, and Joseph Quinn. 2011. "Reentering the labor force after retirement," Monthly Labor Review, 134(6): 34-42.

Cahill, Kevin, Michael Giandrea, and Joseph Quinn. 2018. "Is Bridge Job Activity Overstated?" Work, Aging, and Retirement, 4(4): 330-351.

Clark, Robert, Lee Craig, and John Sabelhaus. 2011. State and Local Retirement Plans in the United States. Northhampton, MA: Edward Elgar Publishing.

Clark, Robert, Robert Hammond, and David Vanderweide. 2019. “Navigating Complex Financial Decisions at Retirement: Evidence from Annuity Choices in Public Sector Pensions,” Journal of Pension Economics and Finance, 18(4):594-611.

Robert Clark, Robert Hammond, and Christelle Khalaf. 2019. "Planning for Retirement? The Importance of Time Preferences,” Journal of Labor Research, 40(2): 127-150.

Clark, Robert, Robert Hammond, Melinda Morrill, and David Vanderweide. 2018. “Annuity Options in Public Pensions Plans: The Curious Case of Social Security Leveling,” Journal of Retirement, 6(1): 33-44.

Clark, Robert and Melinda Morrill. 2010. Retiree Health Plans in the Public Sector: Is There a Funding Crisis? Northhampton, MA: Edward Elgar Publishing. 
Clark, Robert and Melinda Morrill. 2017. Extending Work-Life of Career Employees: Employer Interests and Concerns. Kalamazoo, MI: W.E. Upjohn Institute for Employment Research.

Fitzpatrick, Maria. 2019 forthcoming. "Pension Reform and Return to Work Policies,” Journal of Pension Economics and Finance, 18(4): 500-514.

Franzel, Joshua, Gerald Young, and Rivka Liss-Levinson. November 2018. "Balancing Objectives in Public Employee Post-Retirement Employment Policies," Center for State and Local Government Excellence, https://www.slge.org/assets/uploads/2018/11/slgenasra-post-retirement-employment.pdf

Giandrea, Michael, Kevin Cahill, and Joseph Quinn. 2008. "Self-Employment Transitions among Older American Workers with Career Jobs.” BLS Working Papers No. 418.

Giandrea, Michael, Kevin Cahill, and Joseph Quinn. 2009. “Bridge Jobs: A Comparison across Cohorts.” Research on Aging, 31(5): 549-576.

Hill, Tomeka. 2010. “Why Doesn’t Every Employer Have a Phased Retirement Program?” Benefits Quarterly, 26(4): 29-39.

Johnson, Richard. 2011. "Phased Retirement and Workplace Flexibility for Older Adults: Opportunities and Challenges.” The Annals of the American Academy of Political and Social Science, 638: 68-85.

Johnson, Richard W, Janette Kawachi, and Eric K Lewis. 2009. “Older Workers on the Move: Recareering in Later Life.” AARP Public Policy Institute. Available: http://assets.aarp.org/rgcenter/econ/2009_08_recareering.pdf.

Maestas, Nicole. 2010. "Back to Work: Expectations and Realizations of Work after Retirement.” Journal of Human Resources, 45(3): 718-748.

Pienta, Amy Mehraban, and Mark D. Hayward. 2002. "Who expects to continue working after age 62? The retirement plans of couples.” The Journals of Gerontology Series B: Psychological Sciences and Social Sciences, 57(4), S199-S208. 
Quinn, Joseph. 1980. “Labor Force Participation Patterns of Older Self-Employed Workers.” Social Security Bulletin, 43(4): 17-28.

Quinn, Joseph. 1999. “Retirement Patterns and Bridge Jobs in the 1990s.” Employee Benefit Research Institute (EBRI), Issue Brief No. 206: 1-22.

Quinn, Joseph, Kevin Cahill, and Michael Giandrea. 2019. “Transitions from Career Employment among Public and Private Sector Workers,” Journal of Pension Economics and Finance: 18(4): 529-548.

Ruhm, Christopher. 1990. “Bridge Jobs and Partial Retirement.” Journal of Labor Economics, 8 (4): 482-501.

Zissimopoulos, Julie, and Lynn Karoly. 2009. “Labor Force Dynamics at Older Ages: Movements into Self-Employment for Workers and Nonworkers.” Research on Aging, 31(1): 89-111. 
Figure 1. Distribution of break from work in retirement

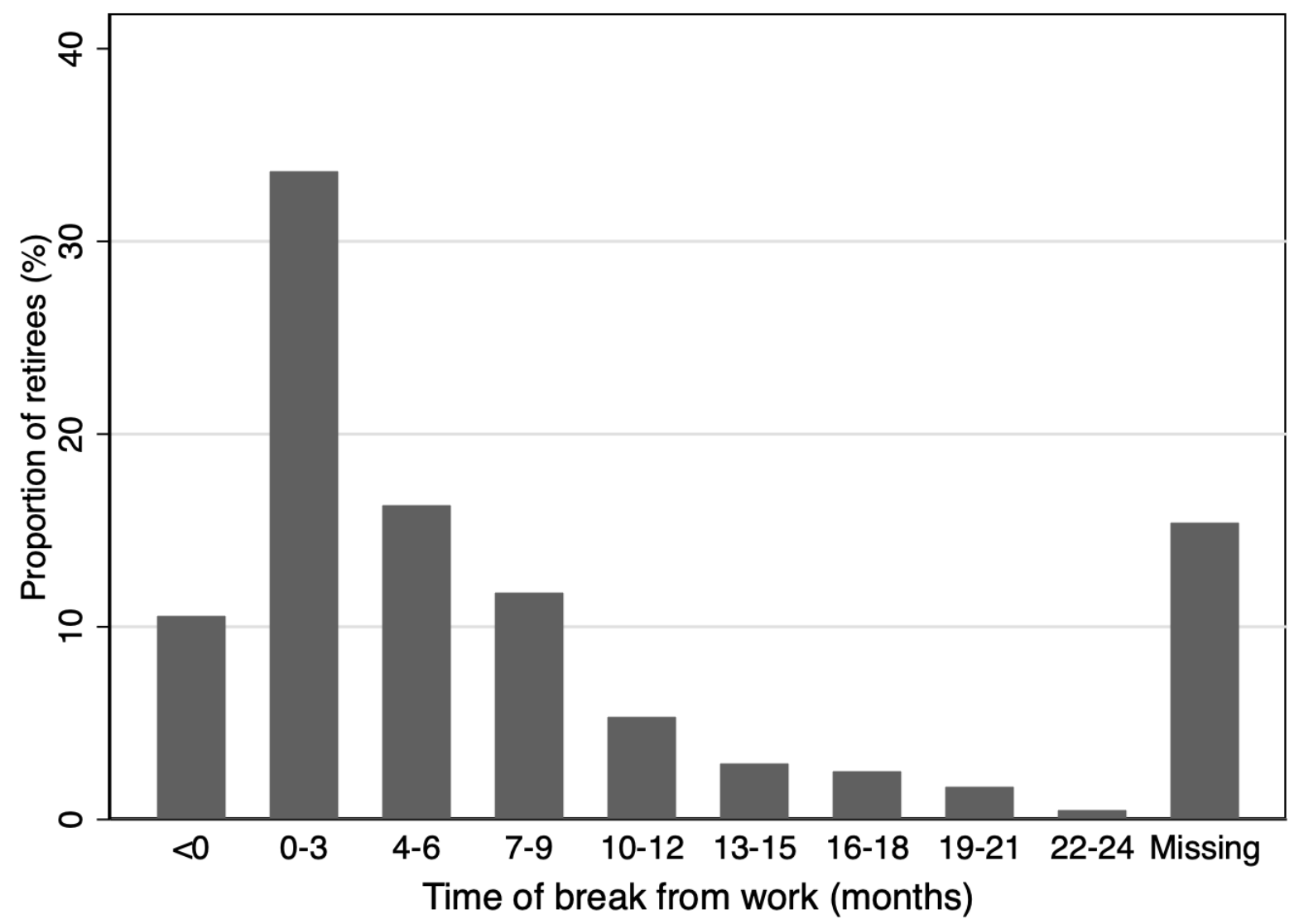

Notes: Author's calculations based on survey responses to date of initial benefit claiming and start time of first job since benefit claiming, conditional on having worked for pay since benefit claiming. 
Table 1. Descriptive Statistics

\begin{tabular}{|c|c|c|c|}
\hline & Full Sample & Sample 1 & Sample 2 \\
\hline$N$ & 590 & 261 & 329 \\
\hline \multirow{2}{*}{ Age as of $3 / 23 / 2016$} & 60.7 & 61.1 & 60.4 \\
\hline & $(4.3)$ & $(4.6)$ & $(4.0)$ \\
\hline \multirow[t]{2}{*}{ Expected retirement age } & 61.4 & 61.0 & 61.7 \\
\hline & $(4.4)$ & $(4.7)$ & $(4.1)$ \\
\hline \multirow[t]{2}{*}{ Years since benefit claiming } & 1.4 & 1.8 & 1.1 \\
\hline & $(0.6)$ & $(0.5)$ & $(0.6)$ \\
\hline K-12 teacher/administrator & $31.5 \%$ & $35.6 \%$ & $28.3 \%$ \\
\hline Police/firefighter & $3.9 \%$ & $2.7 \%$ & $4.9 \%$ \\
\hline University/college faculty/staff & $4.6 \%$ & $3.4 \%$ & $5.5 \%$ \\
\hline Other public employee & $60.0 \%$ & $58.2 \%$ & $61.4 \%$ \\
\hline \multirow[t]{2}{*}{ Annual salary in 2013} & $\$ 60,549$ & $\$ 61,014$ & $\$ 60,179$ \\
\hline & $(24,122)$ & $(25,036)$ & $(23,402)$ \\
\hline \multirow[t]{2}{*}{ Years of service } & 25.4 & 25.5 & - \\
\hline & (8.9) & (8.8) & - \\
\hline Married female & $45.6 \%$ & $46.0 \%$ & $45.3 \%$ \\
\hline Married male & $26.6 \%$ & $24.9 \%$ & $28.0 \%$ \\
\hline Single female & $21.9 \%$ & $22.6 \%$ & $21.3 \%$ \\
\hline Single male & $5.8 \%$ & $6.5 \%$ & $5.2 \%$ \\
\hline African-American/Black & $11.5 \%$ & $15.3 \%$ & $8.5 \%$ \\
\hline White/Caucasian & $80.5 \%$ & $72.8 \%$ & $86.6 \%$ \\
\hline Other race & $6.4 \%$ & $11.5 \%$ & $2.4 \%$ \\
\hline Less than Bachelor's degree & $24.6 \%$ & $19.9 \%$ & $28.3 \%$ \\
\hline Bachelor's degree & $29.5 \%$ & $29.5 \%$ & $29.5 \%$ \\
\hline Master's degree & $36.3 \%$ & $36.4 \%$ & $36.2 \%$ \\
\hline Professional degree/ $\mathrm{PhD}$ & $5.4 \%$ & $4.6 \%$ & $6.1 \%$ \\
\hline Retirement account balances $>250 \mathrm{~K}$ & $25.3 \%$ & $20.7 \%$ & $28.9 \%$ \\
\hline \multirow[t]{2}{*}{ Financial knowledge-number of correct answers } & 2.1 & 2.0 & 2.2 \\
\hline & $(1.0)$ & $(1.1)$ & $(0.9)$ \\
\hline 1-2 children & $58.1 \%$ & $57.5 \%$ & $58.7 \%$ \\
\hline 3 or more children & $19.2 \%$ & $18.0 \%$ & $20.1 \%$ \\
\hline Caregiving for children & $7.6 \%$ & $9.6 \%$ & $6.1 \%$ \\
\hline Caregiving for grandchildren & $14.1 \%$ & $12.6 \%$ & $15.2 \%$ \\
\hline Caregiving for anyone else & $19.2 \%$ & $18.8 \%$ & $19.5 \%$ \\
\hline Self-reported health is good & $84.6 \%$ & $77.4 \%$ & $90.3 \%$ \\
\hline Has any health insurance in retirement & $95.9 \%$ & $92.4 \%$ & $98.5 \%$ \\
\hline Has health insurance provided by own employer in retirement & $89.1 \%$ & $81.7 \%$ & $94.8 \%$ \\
\hline \multirow[t]{2}{*}{ Married*spouse relative age (years) } & -0.6 & -0.5 & -0.7 \\
\hline & $(5.3)$ & $(4.8)$ & $(5.6)$ \\
\hline Married* spouse health good & $83.3 \%$ & $82.7 \%$ & $83.8 \%$ \\
\hline Married*spouse currently working & $51.2 \%$ & $50.8 \%$ & $51.5 \%$ \\
\hline
\end{tabular}

Notes: Data is comprised of two cohorts that include individuals who were working as of March 2014 and had initiated retirement benefits as of May 2016 and individuals who were working as of April 2016 and had initiated retirement benefits as of May 2018. Job classifications, salary, years of service, and gender are drawn from administrative records as of April 2016. Race, education, number of children, and health insurance are drawn from S2016. Expected retirement is drawn from ex-ante surveys. All other variables are drawn from ex-post surveys, S2016 for sample 1, S2018 for sample 2. Details are provided in the appendix. 
Table 2: Characteristics from Worker Survey, Cross-Tab with Post-Claiming Work

\begin{tabular}{|c|c|c|c|c|}
\hline & $\begin{array}{c}\text { Full } \\
\text { sample }\end{array}$ & Pct & $\begin{array}{c}\text { Number } \\
\text { worked }\end{array}$ & $\begin{array}{c}\text { Pct } \\
\text { worked }\end{array}$ \\
\hline$N$ & 590 & & 247 & \\
\hline Has made retirement plans & 404 & $68.5 \%$ & 174 & $43.1 \%$ \\
\hline \multicolumn{5}{|l|}{ Supplemental retirement savings plans: } \\
\hline Retirement saving plan with my current public employer & 394 & $66.8 \%$ & 178 & $45.2 \%$ \\
\hline IRA & 276 & $46.8 \%$ & 126 & $45.7 \%$ \\
\hline Retirement saving plan with my spouse's current employer & 178 & $30.2 \%$ & 80 & $44.9 \%$ \\
\hline \multicolumn{5}{|l|}{ Expected subjective well-being: } \\
\hline Expect to have enough money to live comfortably & 371 & $62.9 \%$ & 159 & $42.9 \%$ \\
\hline Expect to have enough money for medical expenses & 281 & $47.6 \%$ & 118 & $42.0 \%$ \\
\hline Saving the right amount for retirement & 255 & $43.2 \%$ & 104 & $40.8 \%$ \\
\hline Will choose the best way to use savings & 483 & $81.9 \%$ & 201 & $41.6 \%$ \\
\hline Answered plans to work after retirement & 471 & $79.8 \%$ & 222 & $47.1 \%$ \\
\hline \multicolumn{5}{|l|}{ Among those who answered plans to work: } \\
\hline Plan to work after retirement & 357 & $75.8 \%$ & 198 & $55.5 \%$ \\
\hline Plan to work full-time & 50 & $10.6 \%$ & 33 & $66.0 \%$ \\
\hline Plan to work part-time (includes contractor) & 307 & $65.2 \%$ & 165 & $53.7 \%$ \\
\hline Completely retire and never work for pay again & 114 & $24.2 \%$ & 24 & $21.1 \%$ \\
\hline Don’t know & 115 & $19.5 \%$ & 25 & $21.7 \%$ \\
\hline Missing plan to work & 4 & $0.7 \%$ & 0 & $0.0 \%$ \\
\hline \multicolumn{5}{|l|}{$\begin{array}{l}\text { Among those who plan to work: } \\
\text { Reason for plan to work: }\end{array}$} \\
\hline Stay active & 246 & $68.3 \%$ & 135 & $54.9 \%$ \\
\hline Need income & 125 & $34.7 \%$ & 79 & $63.2 \%$ \\
\hline Other & 49 & $13.6 \%$ & 30 & $61.2 \%$ \\
\hline \multicolumn{5}{|l|}{$\begin{array}{l}\text { Among those who don't plan to work: } \\
\text { Reason for not planning to work: }\end{array}$} \\
\hline Expect to have enough money & 62 & $54.4 \%$ & 13 & $21.0 \%$ \\
\hline Health issues & 6 & $5.3 \%$ & 2 & $33.3 \%$ \\
\hline No longer enjoy work & 16 & $14.0 \%$ & 3 & $18.8 \%$ \\
\hline Not able to find work & 11 & $9.6 \%$ & 3 & $27.3 \%$ \\
\hline
\end{tabular}

Notes: Data is comprised of two cohorts that include individuals who were working as of March 2014 and had initiated retirement benefits as of May 2016 and individuals who were working as of April 2016 and had initiated retirement benefits as of May 2018. Details are provided in the appendix. 
Table 3: Characteristics from Post-Claiming Survey

\begin{tabular}{|c|c|c|}
\hline & Count & Pct \\
\hline $\mathbf{N}$ & 590 & \\
\hline Worked after Retirement & 247 & $41.9 \%$ \\
\hline Missing work for pay & 16 & $2.7 \%$ \\
\hline \multicolumn{3}{|l|}{ Among those who worked for pay: } \\
\hline Currently working for pay & 199 & $80.6 \%$ \\
\hline \multicolumn{3}{|l|}{ Descriptions for currently working: } \\
\hline Able to find a suitable position & 141 & $70.9 \%$ \\
\hline Difficult to find current position & 23 & $11.6 \%$ \\
\hline Stay active & 160 & $80.4 \%$ \\
\hline Need income & 140 & $70.4 \%$ \\
\hline Need health benefits & 8 & $4.0 \%$ \\
\hline \multicolumn{3}{|l|}{ Hours worked: } \\
\hline Worked Full-time & 30 & $12.1 \%$ \\
\hline Worked Part-time & 149 & $60.3 \%$ \\
\hline Missing hours of work & 68 & $27.5 \%$ \\
\hline \multicolumn{3}{|l|}{ Time of break from work } \\
\hline$<0$ month & 26 & $10.5 \%$ \\
\hline 0-3 months & 83 & $33.6 \%$ \\
\hline 4-6 months & 40 & $16.2 \%$ \\
\hline 7-12 months & 42 & $17.0 \%$ \\
\hline$>12$ months & 18 & $7.3 \%$ \\
\hline Missing date began working & 23 & $9.3 \%$ \\
\hline Don't know date began working & 3 & $1.2 \%$ \\
\hline Missing date of initial benefit claiming & 12 & $4.9 \%$ \\
\hline \multicolumn{3}{|l|}{ Type of work } \\
\hline Public sector full-time & 10 & $4.0 \%$ \\
\hline Public sector part-time & 68 & $27.5 \%$ \\
\hline Public sector hours not known & 1 & $0.4 \%$ \\
\hline Private sector & 65 & $26.3 \%$ \\
\hline Self-employed & 26 & $10.5 \%$ \\
\hline Other & 11 & $4.5 \%$ \\
\hline Missing type of work & 66 & $26.7 \%$ \\
\hline
\end{tabular}


Table 4: Regression of Plan to Work

\begin{tabular}{lccc} 
& $\mathbf{( 1 )}$ & $\mathbf{( 2 )}$ & $\mathbf{( 3 )}$ \\
\hline Male & $0.206^{* *}$ & $0.202^{* *}$ & $0.203^{* *}$ \\
Married & $(0.095)$ & $(0.095)$ & $(0.094)$ \\
& $-0.085^{*}$ & $-0.093^{*}$ & $-0.093^{*}$ \\
Male * Married & $(0.050)$ & $(0.050)$ & $(0.050)$ \\
& -0.168 & -0.164 & -0.147 \\
Age & $(0.105)$ & $(0.105)$ & $(0.105)$ \\
& $-0.018^{* * *}$ & $-0.018^{* * *}$ & $-0.017^{* * *}$ \\
African American & $(0.004)$ & $(0.004)$ & $(0.004)$ \\
Other race & 0.022 & 0.023 & 0.008 \\
& $(0.063)$ & $(0.063)$ & $(0.064)$ \\
Bachelor's degree or above & 0.138 & 0.143 & 0.116 \\
2013 Salary in \$10k & $(0.091)$ & $(0.090)$ & $(0.092)$ \\
Has 1-2 kids & 0.073 & 0.079 & $0.090^{*}$ \\
Has more than 2 kids & $(0.049)$ & $(0.049)$ & $(0.050)$ \\
Teacher & 0.006 & 0.006 & 0.007 \\
Own health is good & $(0.009)$ & $(0.009)$ & $(0.009)$ \\
Expected mortality 85+ & $0.127^{* *}$ & $0.126^{* *}$ & $0.125^{* *}$ \\
High financial knowledge & $(0.051)$ & $(0.051)$ & $(0.051)$ \\
Risk averse & $0.126^{* *}$ & $0.128^{* *}$ & $0.130^{* *}$ \\
N & $(0.062)$ & $(0.062)$ & $(0.062)$ \\
& 0.115 & 0.109 & 0.107 \\
Notes: Dampatient & $(0.074)$ & $(0.074)$ & $(0.073)$ \\
& & 0.065 & 0.067 \\
& & $(0.068)$ & $(0.069)$ \\
& & -0.033 & -0.027 \\
& & & $(0.040)$ \\
& & & $-0.085^{* *}$ \\
& & & -0.034 \\
& & & $-0.040)$ \\
& & 571 & $(0.041)$ \\
& & 571 \\
\hline
\end{tabular}

Notes: Data is comprised of two cohorts that include individuals who were working as of March 2014 and had initiated retirement benefits as of May 2016 and individuals who were working as of April 2016 and had initiated retirement benefits as of May 2018. Dependent variable is planning to work after retirement while still working. Coefficients are average marginal effects from a probit model with standard errors in parentheses. All specifications include agency type and year of claiming fixed effects. Details are provided in the appendix. ${ }^{* * *} \mathrm{p}<0.01,{ }^{* *} \mathrm{p}<0.05,{ }^{*} \mathrm{p}<0.1$ 
Table 5: Regression of Work after Retirement

\begin{tabular}{|c|c|c|c|c|}
\hline & (1) & (2) & (3) & (4) \\
\hline Plan to work & $\begin{array}{c}0.301 * * * \\
(0.048)\end{array}$ & $\begin{array}{c}0.302 * * * \\
(0.048)\end{array}$ & $\begin{array}{c}0.296 * * * \\
(0.048)\end{array}$ & $\begin{array}{c}0.282^{* * *} \\
(0.049)\end{array}$ \\
\hline DK plan to work & $\begin{array}{c}0.009 \\
(0.068)\end{array}$ & $\begin{array}{c}0.010 \\
(0.067)\end{array}$ & $\begin{array}{c}0.004 \\
(0.068)\end{array}$ & $\begin{array}{c}0.004 \\
(0.067)\end{array}$ \\
\hline Male & $\begin{array}{c}0.093 \\
(0.095)\end{array}$ & $\begin{array}{c}0.106 \\
(0.094)\end{array}$ & $\begin{array}{c}0.112 \\
(0.095)\end{array}$ & $\begin{array}{c}0.099 \\
(0.094)\end{array}$ \\
\hline Married & $\begin{array}{c}0.017 \\
(0.051)\end{array}$ & $\begin{array}{c}0.017 \\
(0.051)\end{array}$ & $\begin{array}{c}0.017 \\
(0.051)\end{array}$ & $\begin{array}{c}0.020 \\
(0.050)\end{array}$ \\
\hline Male * Married & $\begin{array}{c}-0.071 \\
(0.105)\end{array}$ & $\begin{array}{c}-0.071 \\
(0.104)\end{array}$ & $\begin{array}{c}-0.072 \\
(0.104)\end{array}$ & $\begin{array}{l}-0.063 \\
(0.104)\end{array}$ \\
\hline Age & $\begin{array}{c}-0.018 * * * \\
(0.004)\end{array}$ & $\begin{array}{c}-0.018 * * * \\
(0.004)\end{array}$ & $\begin{array}{c}-0.018 * * * \\
(0.004)\end{array}$ & $\begin{array}{c}-0.015^{* * * *} \\
(0.005)\end{array}$ \\
\hline African American & $\begin{array}{c}-0.130 * * \\
(0.063)\end{array}$ & $\begin{array}{c}-0.114^{*} \\
(0.064)\end{array}$ & $\begin{array}{c}-0.123^{*} \\
(0.065)\end{array}$ & $\begin{array}{c}-0.118^{*} \\
(0.064)\end{array}$ \\
\hline Other race & $\begin{array}{l}-0.085 \\
(0.093)\end{array}$ & $\begin{array}{l}-0.024 \\
(0.097)\end{array}$ & $\begin{array}{l}-0.031 \\
(0.099)\end{array}$ & $\begin{array}{l}-0.028 \\
(0.098)\end{array}$ \\
\hline Bachelor's degree or above & $\begin{array}{c}0.041 \\
(0.050)\end{array}$ & $\begin{array}{c}0.028 \\
(0.050)\end{array}$ & $\begin{array}{c}0.033 \\
(0.051)\end{array}$ & $\begin{array}{c}0.020 \\
(0.051)\end{array}$ \\
\hline 2013 Salary in $\$ 10 \mathrm{k}$ & $\begin{array}{l}0.016^{*} \\
(0.009)\end{array}$ & $\begin{array}{c}0.014 \\
(0.009)\end{array}$ & $\begin{array}{l}0.015^{*} \\
(0.009)\end{array}$ & $\begin{array}{l}0.015^{*} \\
(0.009)\end{array}$ \\
\hline Has 1 -2 kids & $\begin{array}{l}-0.010 \\
(0.051)\end{array}$ & $\begin{array}{l}-0.016 \\
(0.051)\end{array}$ & $\begin{array}{l}-0.017 \\
(0.051)\end{array}$ & $\begin{array}{l}-0.020 \\
(0.051)\end{array}$ \\
\hline Has more than 2 kids & $\begin{array}{c}0.017 \\
(0.063)\end{array}$ & $\begin{array}{c}0.004 \\
(0.063)\end{array}$ & $\begin{array}{c}-0.000 \\
(0.063)\end{array}$ & $\begin{array}{l}-0.015 \\
(0.065)\end{array}$ \\
\hline Teacher & $\begin{array}{c}0.184^{* *} \\
(0.075)\end{array}$ & $\begin{array}{c}0.192 * * \\
(0.075)\end{array}$ & $\begin{array}{c}0.190 * * \\
(0.075)\end{array}$ & $\begin{array}{c}0.167 * * \\
(0.075)\end{array}$ \\
\hline Own health is good & & $\begin{array}{l}0.118^{*} \\
(0.064)\end{array}$ & $\begin{array}{l}0.126^{*} \\
(0.065)\end{array}$ & $\begin{array}{l}0.122^{*} \\
(0.064)\end{array}$ \\
\hline Expected mortality 85+ & & $\begin{array}{c}0.060 \\
(0.045)\end{array}$ & $\begin{array}{c}0.060 \\
(0.045)\end{array}$ & $\begin{array}{c}0.048 \\
(0.045)\end{array}$ \\
\hline High financial knowledge & & & $\begin{array}{l}-0.047 \\
(0.041)\end{array}$ & $\begin{array}{l}-0.046 \\
(0.041)\end{array}$ \\
\hline Time impatient & & & $\begin{array}{l}-0.016 \\
(0.040)\end{array}$ & $\begin{array}{l}-0.019 \\
(0.040)\end{array}$ \\
\hline Risk averse & & & $\begin{array}{c}0.002 \\
(0.041)\end{array}$ & $\begin{array}{c}0.002 \\
(0.041)\end{array}$ \\
\hline Cared for children & & & & $\begin{array}{c}0.184^{* *} \\
(0.077)\end{array}$ \\
\hline Cared for grandchildren & & & & $\begin{array}{l}-0.036 \\
(0.056)\end{array}$ \\
\hline Cared for anyone else & & & & $\begin{array}{c}0.066 \\
(0.049)\end{array}$ \\
\hline $\mathrm{N}$ & 571 & 571 & 571 & 571 \\
\hline
\end{tabular}


Table 6: Regression of Retirement Income Well-being

\begin{tabular}{|c|c|c|c|c|c|c|}
\hline & $\begin{array}{c}\text { Best } \\
\text { timing } \\
(1)\end{array}$ & $\begin{array}{c}\text { Best } \\
\text { annuity } \\
\text { (2) }\end{array}$ & $\begin{array}{c}\text { Enough } \\
\text { info } \\
\text { (3) }\end{array}$ & $\begin{array}{c}\text { Saved } \\
\text { enough } \\
(4)\end{array}$ & $\begin{array}{c}\text { Confident } \\
\text { (5) }\end{array}$ & $\begin{array}{c}\text { Satisfied } \\
\text { (6) }\end{array}$ \\
\hline Plan to work & $\begin{array}{c}-0.044 \\
(0.055)\end{array}$ & $\begin{array}{c}-0.011 \\
(0.045)\end{array}$ & $\begin{array}{l}-0.048 \\
(0.055)\end{array}$ & $\begin{array}{c}-0.126^{* *} \\
(0.058)\end{array}$ & $\begin{array}{c}-0.153^{* * *} \\
(0.056)\end{array}$ & $\begin{array}{c}-0.127 * * \\
(0.062)\end{array}$ \\
\hline DK plan to work & $\begin{array}{c}-0.111^{*} \\
(0.057)\end{array}$ & $\begin{array}{l}-0.033 \\
(0.049)\end{array}$ & $\begin{array}{l}-0.044 \\
(0.059)\end{array}$ & $\begin{array}{l}-0.073 \\
(0.061)\end{array}$ & $\begin{array}{c}-0.103^{*} \\
(0.059)\end{array}$ & $\begin{array}{l}-0.079 \\
(0.067)\end{array}$ \\
\hline Worked & $\begin{array}{c}0.039 \\
(0.069)\end{array}$ & $\begin{array}{c}0.016 \\
(0.058)\end{array}$ & $\begin{array}{c}0.045 \\
(0.070)\end{array}$ & $\begin{array}{c}0.035 \\
(0.068)\end{array}$ & $\begin{array}{c}0.078 \\
(0.067)\end{array}$ & $\begin{array}{c}0.085 \\
(0.079)\end{array}$ \\
\hline Plan to work * Worked & $\begin{array}{c}-0.142 * \\
(0.080)\end{array}$ & $\begin{array}{l}-0.000 \\
(0.068)\end{array}$ & $\begin{array}{l}-0.021 \\
(0.081)\end{array}$ & $\begin{array}{l}-0.067 \\
(0.083)\end{array}$ & $\begin{array}{l}-0.126 \\
(0.082)\end{array}$ & $\begin{array}{l}-0.059 \\
(0.092)\end{array}$ \\
\hline Male & $\begin{array}{c}0.116 \\
(0.094)\end{array}$ & $\begin{array}{l}-0.034 \\
(0.069)\end{array}$ & $\begin{array}{c}0.026 \\
(0.087)\end{array}$ & $\begin{array}{c}0.268^{* * * *} \\
(0.096)\end{array}$ & $\begin{array}{c}0.243^{* * *} \\
(0.092)\end{array}$ & $\begin{array}{c}0.076 \\
(0.099)\end{array}$ \\
\hline Married & $\begin{array}{c}0.003 \\
(0.043)\end{array}$ & $\begin{array}{c}0.022 \\
(0.037)\end{array}$ & $\begin{array}{l}-0.025 \\
(0.043)\end{array}$ & $\begin{array}{c}0.182 * * * \\
(0.052)\end{array}$ & $\begin{array}{c}0.060 \\
(0.050)\end{array}$ & $\begin{array}{c}0.041 \\
(0.049)\end{array}$ \\
\hline Male * Married & $\begin{array}{l}-0.114 \\
(0.101)\end{array}$ & $\begin{array}{c}0.058 \\
(0.077)\end{array}$ & $\begin{array}{c}0.052 \\
(0.096)\end{array}$ & $\begin{array}{c}-0.209 * * \\
(0.105)\end{array}$ & $\begin{array}{l}-0.070 \\
(0.102)\end{array}$ & $\begin{array}{c}0.009 \\
(0.109)\end{array}$ \\
\hline Age & $\begin{array}{c}-0.008^{*} \\
(0.004)\end{array}$ & $\begin{array}{c}0.001 \\
(0.003)\end{array}$ & $\begin{array}{c}0.006 \\
(0.004)\end{array}$ & $\begin{array}{c}0.002 \\
(0.005)\end{array}$ & $\begin{array}{c}0.007 \\
(0.005)\end{array}$ & $\begin{array}{c}0.003 \\
(0.005)\end{array}$ \\
\hline African American & $\begin{array}{l}-0.010 \\
(0.053)\end{array}$ & $\begin{array}{l}-0.007 \\
(0.045)\end{array}$ & $\begin{array}{l}-0.028 \\
(0.053)\end{array}$ & $\begin{array}{c}0.026 \\
(0.064)\end{array}$ & $\begin{array}{l}-0.022 \\
(0.063)\end{array}$ & $\begin{array}{l}-0.013 \\
(0.062)\end{array}$ \\
\hline Other race & $\begin{array}{c}0.073 \\
(0.115)\end{array}$ & $\begin{array}{c}0.008 \\
(0.091)\end{array}$ & $\begin{array}{c}0.047 \\
(0.112)\end{array}$ & $\begin{array}{c}0.040 \\
(0.119)\end{array}$ & $\begin{array}{l}-0.219 \\
(0.137)\end{array}$ & $\begin{array}{l}-0.060 \\
(0.122)\end{array}$ \\
\hline Bachelor's degree or above & $\begin{array}{c}0.034 \\
(0.044)\end{array}$ & $\begin{array}{c}0.048 \\
(0.037)\end{array}$ & $\begin{array}{c}0.034 \\
(0.045)\end{array}$ & $\begin{array}{l}-0.027 \\
(0.052)\end{array}$ & $\begin{array}{c}-0.051 \\
(0.051)\end{array}$ & $\begin{array}{c}0.028 \\
(0.052)\end{array}$ \\
\hline 2013 Salary in $\$ 10 \mathrm{k}$ & $\begin{array}{l}-0.005 \\
(0.008)\end{array}$ & $\begin{array}{c}0.011 \\
(0.008)\end{array}$ & $\begin{array}{c}0.014 \\
(0.009)\end{array}$ & $\begin{array}{c}0.033 * * * \\
(0.009)\end{array}$ & $\begin{array}{c}0.032 * * * \\
(0.008)\end{array}$ & $\begin{array}{c}0.025^{* *} \\
(0.010)\end{array}$ \\
\hline Has 1-2 kids & $\begin{array}{l}-0.015 \\
(0.046)\end{array}$ & $\begin{array}{c}-0.088^{* *} \\
(0.044)\end{array}$ & $\begin{array}{l}-0.016 \\
(0.046)\end{array}$ & $\begin{array}{c}-0.147 * * * \\
(0.050)\end{array}$ & $\begin{array}{c}-0.144^{* * *} \\
(0.049)\end{array}$ & $\begin{array}{c}-0.122^{* *} \\
(0.054)\end{array}$ \\
\hline Has more than 2 kids & $\begin{array}{l}-0.045 \\
(0.057)\end{array}$ & $\begin{array}{c}-0.121^{* *} \\
(0.051)\end{array}$ & $\begin{array}{c}0.008 \\
(0.059)\end{array}$ & $\begin{array}{c}-0.136^{* *} \\
(0.062)\end{array}$ & $\begin{array}{c}-0.176^{* * *} \\
(0.061)\end{array}$ & $\begin{array}{l}-0.096 \\
(0.067)\end{array}$ \\
\hline Teacher & $\begin{array}{l}-0.093 \\
(0.070)\end{array}$ & $\begin{array}{l}-0.042 \\
(0.058)\end{array}$ & $\begin{array}{l}-0.005 \\
(0.068)\end{array}$ & $\begin{array}{c}0.074 \\
(0.077)\end{array}$ & $\begin{array}{l}-0.032 \\
(0.072)\end{array}$ & $\begin{array}{c}-0.157 * * \\
(0.077)\end{array}$ \\
\hline Own health is good & $\begin{array}{c}0.142 * * * \\
(0.049)\end{array}$ & $\begin{array}{c}0.137 * * * \\
(0.039)\end{array}$ & $\begin{array}{c}0.109^{* *} \\
(0.050)\end{array}$ & $\begin{array}{c}0.291 * * * \\
(0.071)\end{array}$ & $\begin{array}{c}0.047 \\
(0.060)\end{array}$ & $\begin{array}{c}0.225^{* * *} \\
(0.057)\end{array}$ \\
\hline Expected mortality 85+ & $\begin{array}{c}0.065 \\
(0.040)\end{array}$ & $\begin{array}{l}0.069 * \\
(0.037)\end{array}$ & $\begin{array}{c}0.005 \\
(0.040)\end{array}$ & $\begin{array}{c}0.093 * * \\
(0.042)\end{array}$ & $\begin{array}{c}0.065 \\
(0.042)\end{array}$ & $\begin{array}{c}0.024 \\
(0.045)\end{array}$ \\
\hline Time impatient & $\begin{array}{l}-0.012 \\
(0.036)\end{array}$ & $\begin{array}{l}-0.032 \\
(0.031)\end{array}$ & $\begin{array}{c}0.008 \\
(0.037)\end{array}$ & $\begin{array}{c}0.041 \\
(0.040)\end{array}$ & $\begin{array}{c}0.053 \\
(0.040)\end{array}$ & $\begin{array}{c}0.024 \\
(0.041)\end{array}$ \\
\hline Risk averse & $\begin{array}{c}0.005 \\
(0.034)\end{array}$ & $\begin{array}{c}0.000 \\
(0.030)\end{array}$ & $\begin{array}{c}0.018 \\
(0.035)\end{array}$ & $\begin{array}{l}-0.020 \\
(0.039)\end{array}$ & $\begin{array}{c}0.005 \\
(0.039)\end{array}$ & $\begin{array}{l}-0.035 \\
(0.040)\end{array}$ \\
\hline High financial knowledge & $\begin{array}{l}-0.023 \\
(0.035)\end{array}$ & $\begin{array}{c}0.021 \\
(0.031)\end{array}$ & $\begin{array}{c}0.008 \\
(0.037)\end{array}$ & $\begin{array}{c}0.021 \\
(0.040)\end{array}$ & $\begin{array}{l}-0.049 \\
(0.039)\end{array}$ & $\begin{array}{c}0.034 \\
(0.041)\end{array}$ \\
\hline Cared for children & $\begin{array}{l}-0.068 \\
(0.061)\end{array}$ & $\begin{array}{c}-0.095^{*} \\
(0.050)\end{array}$ & $\begin{array}{l}-0.100 \\
(0.063)\end{array}$ & $\begin{array}{l}-0.092 \\
(0.076)\end{array}$ & $\begin{array}{l}-0.014 \\
(0.075)\end{array}$ & $\begin{array}{l}-0.124^{*} \\
(0.072)\end{array}$ \\
\hline Cared for grandchildren & $\begin{array}{c}0.072 \\
(0.050)\end{array}$ & $\begin{array}{l}0.079 * \\
(0.044)\end{array}$ & $\begin{array}{l}0.102^{*} \\
(0.054)\end{array}$ & $\begin{array}{l}-0.030 \\
(0.055)\end{array}$ & $\begin{array}{l}-0.040 \\
(0.054)\end{array}$ & $\begin{array}{l}-0.004 \\
(0.056)\end{array}$ \\
\hline Cared for anyone else & 0.038 & 0.000 & 0.012 & $-0.104 * *$ & $-0.125 * *$ & -0.063 \\
\hline
\end{tabular}


Notes: Data is comprised of two cohorts that include individuals who were working as of March 2014 and had initiated retirement benefits as of May 2016 and individuals who were working as of April 2016 and had initiated retirement benefits as of May 2018. Dependent variables are indicated in column headings. Coefficients are average marginal effects from a probit model with standard errors in parentheses. All specifications include agency type and year of claiming fixed effects. Details are provided in the appendix. ${ }^{* * *} \mathrm{p}<0.01, * * \mathrm{p}<0.05, * \mathrm{p}<0.1$ 